\title{
SEED (STROKE DISEASE EARLY DETECTION APPLICATION) - RANCANG BANGUN APLIKASI MOBILE BERBASIS ANDROID UNTUK MENDIAGNOSIS GEJALA DINI PENYAKIT STROKE MENGGUNAKAN K-NEAREST NEIGHBOR (K-NN)
}

\author{
Dedin Anike Putra1, Muhammad Dimas Setiawan Sanapiah², Azifatul Istna Hanifah' ${ }^{3}$, Tri Afirianto ${ }^{4}$ \\ ${ }^{1234}$ Fakultas Ilmu Komputer, Universitas Brawijaya \\ Email: ${ }^{1}$ dedinaputra2@gmail.com, ${ }^{2}$ dimsetiawan_toke@yahoo.com, ${ }^{3}$ zifahanifah@gmail.com, \\ tri.afirianto@ub.ac.id
}

(Naskah masuk: 12 Juli 2018, diterima untuk diterbitkan: 13 Februari 2019)

\begin{abstract}
Abstrak
Stroke merupakan penyakit yang tinggi di Indonesia. Stroke menjadi peringkat kedua sebagai penyakit yang paling banyak menyebabkan kematian didunia. Pada zaman modern, stroke tidak hanya menyerang orang yang sudah lanjut usia namun juga bisa menyerang orang usia muda. Data dari Rumah Sakit Saiful Anwar (RSSA) Kota Malang, sepanjang tahun 2016 penderita penyakit stroke $30 \%$ nya masih diusia muda, yaitu antara usia $18-40$ tahun. Salah satu solusi untuk mencegah penyakit stroke adalah dengan mendeteksi gejala-gejala dini yang bisa mengakibatkan penyakit tersebut terjadi. Salah satu metode yang bisa dilakukan adalah dengan menggunakan metode kecerdasan buatan. Metode ini akan lebih mudah diimplementasikan dalam bentuk program atau aplikasi. Aplikasi membuat pengguna dapat lebih mudah membaca dan menerima pelaporan melalui fitur-fitur yang disediakan. SEED (Stroke Disease Early Detection Application) adalah sebuah aplikasi berbasis android untuk mendiagnosis gejala dini penyakit stroke menggunakan algoritma klasifikasi k-NN. Algoritma k-NN dipilih lantaran pada penelitian sebelumnya menghasilkan tingkat akurasi yang relatif tinggi. SEED dibangun menggunakan metode prototyping. Metode prototyping merupakan salah satu jenis software development lifecycle (SDLC) dalam pengembangan perangkat lunak. Terdapat empat fitur utama pada SEED, yaitu 1) klasifikasi dan rekomendasi, 2) riwayat, 3) informasi kesehatan, serta 4) masuk dan daftar. Proses klasifikasi dibagi kedalam tiga tingkatan, yaitu risiko rendah, sedang, dan tinggi. Fitur-fitur yang digunakan untuk proses klasifikasi diantaranya adalah : 1) tinggi badan, berat badan, indeks masa tubuh, tekanan darah, riwayat fibrilasi atrium, riwayat keluarga, kebiasaan merokok, aktivitas fisik, tingkat kolesterol, serta diabetes. Berdasarkan hasil pengujian, didapatkan tingkat validasi kebutuhan sebesar $100 \%$, tingkat akurasi pengklasifikasian sebesar $88 \%$. dan tingkat penerimaan pengguna sebesar $78 \%$.
\end{abstract}

Kata kunci: Stroke, Apilkasi Mobile, $k-N N$

\section{SEED (STROKE DISEASE EARLY DETECTION APPLICATION) - MOBILE APPLICATION FOR DIAGNOSING EARLY SYMPTOMPS OF STROKE DISEASE USING K-NEAREST NEIGHBOR SYSTEM DESIGN}

\begin{abstract}
Stroke is one of the highest disease in Indonesia. Stroke become the second most common cause of deadly disease in the world In modern era, young people can get this disease. Data from Syaiful Anwar Hospital (RSSA) Malang City shows that 30\% of stroke patient's age is among 18-30 years old. Preventif action needs to be done for reducing the risk level of stroke. One of them is using artificial intelegence technique. These method can be implemented by creating a programme or an application. Application also make a user more convenient to access through its features. SEED (Stroke Disease Early Detection Application) is an android based application that can measure the risk level of stroke disease. This algorith choosen because of its previous accuracy. prototyping model used to develop this application. There are four main features of seed : 1) classification and recommendation, 2) history, 3) health information, and 4) login and register. Risk level of prediction is consists of low, middle, and high risk. Features used in SEED are height, weight, blood pressure, history of atrial fibrillation, history of family, smoking habbit, phisical exercise habbit, cholesterol, and blood sugarit makes. Based on testing phase, The application gain validation test is up to $100 \%$, Its accuracy of classification is up to $88 \%$, and its acceptance test is up to $78 \%$.
\end{abstract}

Keywords: Stroke, Mobile Application, $k-N N$ 


\section{PENDAHULUAN}

\subsection{Latar Belakang}

Stroke merupakan salah satu penyakit yang menyebabkan kematian terbanyak di Indonesia. Pada tahun 2013 pravelensi stroke di Indonesia mencapai 12,1 per 1000 penduduk (Badan Penelitian dan Pengembangan Kesehatan RI, 2013). Hal ini membuat stroke menjadi penyakit keempat tertinggi yang diderita oleh masyarakat Indonesia. Sedangkan di seluruh dunia, stroke menduduki peringkat kedua sebagai penyakit yang menyebabkan kematian, dengan presentasi $11,13 \%$, dari total kematian yang ada (Mozaffarian, 2015 disitasi dalam Syafiq, Muhammad, 2016). Stroke kebanyakan diderita oleh orang yang berusia 40-an tahun. Namun saat ini, tidak menutup kemungkinan diusia muda juga terserang stroke. Data dari Rumah Sakit Saiful Anwar (RSSA) Kota Malang, sepanjang tahun 2016 penderita penyakit stroke $30 \%$ nya masih diusia muda, yaitu antara usia 18 - 40 tahun (Arisetijono, 2016). Hal ini dikarenakan pola hidup yang tidak sehat.

Pada umumnya perlu dokter spesialis untuk mendiagnosis penyakit stroke pada salah seorang pasien. Dokter spesialis akan membaca hasil CT (Computed Tomography) atau pun MRI (Magnetic Resonance Imaging) untuk mendiagnosis pasien tersebut. Namun dengan menggunakan kedua alat tersebut biaya yang ditanggung pasien tidaklah murah. Sehingga telah banyak riset yang dilakukan untuk mengembangkan perangkat pendiagnosis stroke yang lebih terjangkau. Salah satunya adalah riset mendiagnosis penyakit stroke dengan pendekatan pattern recognition atau pengenalan pola dengan menerapkan metode kecerdasan buatan.

Riset yang telah dilakukan dalam mendiagnosis penyakit stroke menggunakan metode PTVPSO-SVM, menghasilkan tingkat akurasi $87 \%$ (Syafiq, Muhammad, dkk., 2016). Riset tersebut dilakukan dengan mengklasifikasikan data dengan 4 fitur, yaitu total kolesterol, HDL, LDL, dan trigliserida. Metode lain yang diterapkan adalah KNN (K-Nearest Neighbour) yang terbukti lebih efektif dibanding MMD (Minimum Mean Distance) untuk mendiagnosis stroke (Sudharani K., dkk., 2015).

K-NN adalah salah satu jenis metode klasifikasi yang banyak digunakan didunia. K-NN dapat mendiagnosis penyakit pada sapi potong dengan tingkat akurasi 100\% (Kurnianingtyas, Diva, dkk., 2017). Selain itu, metode ini juga dapat mendiagnosis tingkatan stroke dengan akurasi $87 \%$ (Suci, Wahyu, dkk., 2017). Untuk itu perlu dibuat suatu mobile apps yang menerapkan metode klasifikasi K-NN dalam mendiagnosis stroke.

Mobile apps merupakan sarana termudah bagi orang awam untuk mendapatkan atau mengakses informasi kapan pun dan dimanapun. Pada saat ini, Aplikasi mobile berbasis android adalah aplikasi yang paling banyak digunakan. 82,83\% Masyarakat Indonesia mengakses internet menggunakan aplikasi berbasis andorid (Statcounter.com, 2018). Perlu dirancang suatu mobile apps berbasis android yang menerapkan K-NN untuk mendiagnosis penyakit tersebut.

SEED (Stroke Disease Early Detection) adalah sebuah perangkat mobile yang menerapkan K-NN untuk mendiagnosis penyakit stroke. Pembuatan aplikasi ini didasarkan pada kesulitan pengguna untuk mengontrol kesehatannya dalam rangka mencegah penyakit stroke. Tingkat kemudahan pengguna dalam menggunakan aplikasi perlu untuk diketahui. Selain itu, nilai akurasi perhitungan k-NN yang diterapkan pada aplikasi berbasis mobile juga harus ditentukan agar menambah tingkat kepercayaan pengguna.

\section{METODOLOGI PENELITIAN DAN PERANCANGAN}

Penelitian dilakukan dengan melalui tahapantahapan dibawah ini. Karena menggunakan pendekatan prototyping, iterasi yang dilakukan dibatasi maksimal 3 kali. Proses pengembangan sistem akan dilakukan dengan pendekatan object oriented dan user centered design.

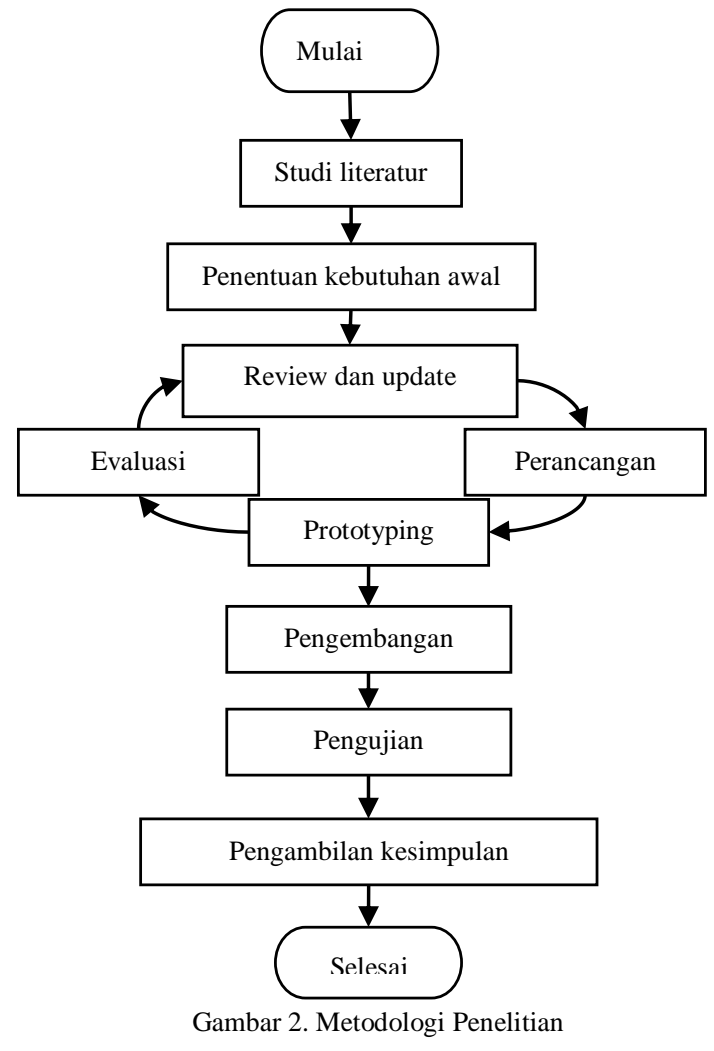

Tahap penggalian dilakukan secara iteratif melalui pakar syaraf yang ada di Rumah Sakit Syaiful Anwar Kota Malang. Penggalian kebutuhan akan mendasari perbaikan dari kebutuhan awal yang telah ditentukan. Kebutuhan akhir akan direpresentasikan menggunakan use case diagram yang menunjukkan 
juga fungsionalitas aplikasi. Gambar 3 menunjukkan fungsionalitas yang bida dilakukan oleh aplikasi.

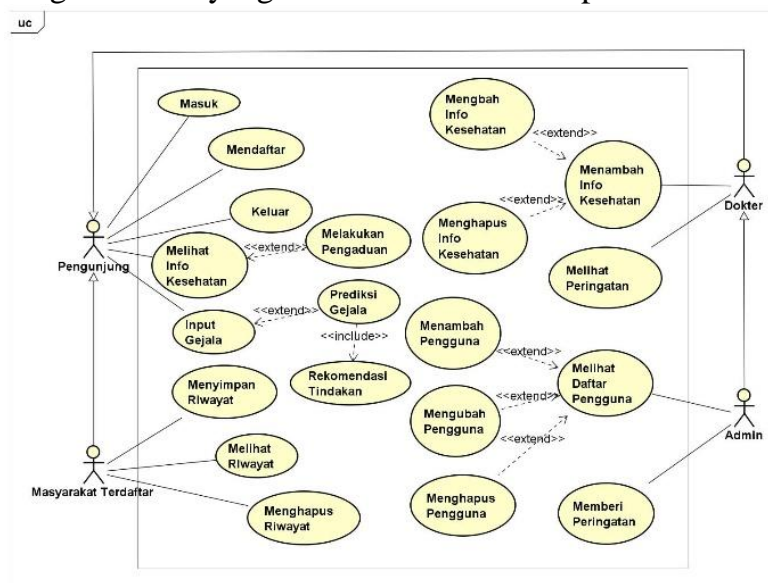

Gambar 3. Use Case Diagram

Paper protoyping digunakan selama proses interasi untuk berkomunikasi dengan pakar. Paper prototyping digunakan agar pakar lebih mudah memahami aplikasi yang akan dibuat. Gambar 4 menunjukkan sampel dari paper prototyping yang telah dilakukan. Hasil dari paper paper prototyping akan ditransformasikan dalam bentuk interaction map (Gambar 5) yang memiliki batasan sesuai dengan fungsionalitas yang telah didefinisikan sebelumnya.

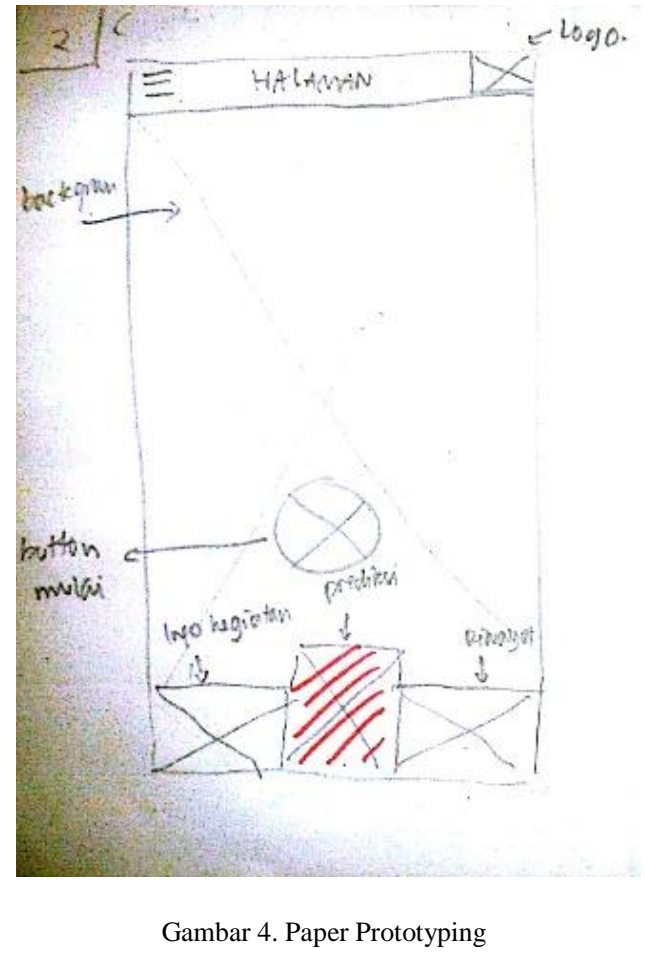

\section{IMPLEMENTASI DAN PEMBAHASAN}

\subsection{Lingkungan Implementasi}

Batasan implementasi perangkat keras yang digunakan saat mengembangkan aplikasi ini adalah :

1. Smarthone Xiaomi Redmi Note 5A

2. Laptop ASUS RAM 6GB Intel Core I3 CPU 2.2 $\mathrm{GHz}$

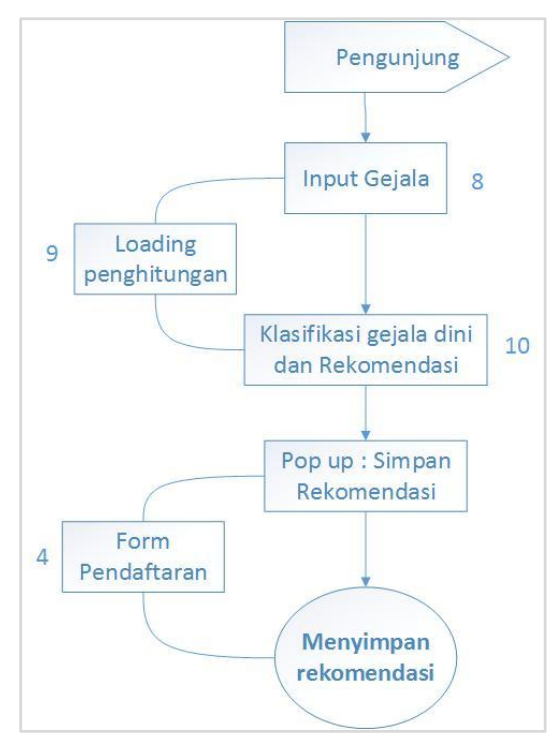

Gambar 5. Interaction Map

Perangkat lunak yang digunakan untuk implementasi aplikasi ini adalah :

1. Apache Web Server

2. MySQL Database

3. Ionic Framework

\subsection{Implementasi database}

Aplikasi mobile berbasis hybrid memerlukan database pada web server untuk menyimpan dan mengolah data. Oleh karena itu, basis data yang digunakan diimplementasikan pada web server dengan menggunakan MySQL database. Gambar 6 menunjukkan physical data model (PDM) yang diimplementasikan pada sisi server.

\subsection{Implementasi Antarmuka}

Implementasi antarmuka didasarkan pada hasil paper prototyping yang telah dilakukan. Antar muka diimplementasikan menggunakan CSS3 yang telah disesuaikan dengan kerangka kerja Ionic. Gambar 7 10 menunjukkan sampel dari implementasi antar muka.

\subsection{Implementasi k-NN}

SEED mengimplementasikan perhitungan k-NN pada sisi server. Sehingga, kode program k-NN diimplementasikan menggunakan bahasa PHP. Terdapat tiga kelas yang ditentukan, yaitu kelas rendah, sedang dan tinggi.

Vote dilakukan dengan menggunakan unweighted vote dengan nilai $\mathrm{k}=3$. Terdapat pembobotan pada perhitungan beberapa fitur yaitu riwayat keluarga (4 kali) dan riwayat fibrilasi atrium ( 2 kali). Aturan tambahan ditambahkan apabila ketiga kelas memiliki nilai vote yang sama (setiap kelas memiliki 1 vote), maka nilai $\mathrm{k}$ diubah menjadi 4 . 
Implementasi PHP dapat dilihat pada Kode Program 1.

\begin{tabular}{|c|c|}
\hline No & Kode Program 1 \\
\hline 1 & $\begin{array}{l}\text { \$tinggi_badan = filter_var }(\$ o b j- \\
\text { >tinggi_badan, } \\
\text { FILTER_SANITIZE_NUMBER_INT); }\end{array}$ \\
\hline 2 & $\begin{array}{l}\text { \$berat_badan = filter_var }(\$ o b j- \\
\text { >berat_badan, } \\
\text { FILTER_SANITIZE_NUMBER_INT) } ;\end{array}$ \\
\hline 3 & $\begin{array}{lcc}\text { \$fibrilasi } & = & \text { fillter_var }(\$ o b j- \\
\text { >fibrilasi, } & \text { FILTER_SANITIZE_STRING, } \\
\text { FILTER_FLAG_ENCODE_LOW); }\end{array}$ \\
\hline 4 & $\begin{array}{l}\text { \$riwayat_keluarga }=\text { filter_var(\$obj- } \\
\text { >riwayat_keluarga, } \\
\text { FILTER_SANITIZE_STRING, } \\
\text { FILTER_FLAG_ENCODE_LOW); }\end{array}$ \\
\hline 5 & $\begin{array}{l}\text { \$ttekanān_darah }=- \text { filter_var(\$obj- } \\
\text { >tekanan_darah, } \\
\text { FILTER_SANITIZE_STRING, } \\
\text { FILTER_FLAG_ENCODE_LOW); }\end{array}$ \\
\hline 6 & $\begin{array}{l}\text { \$merokok }=\text { filter_var }(\$ o b j->\text { merokok, } \\
\text { FILTER_SANITIZE_STRING, } \\
\text { FILTER_FLAG_ENCODE_LOW); }\end{array}$ \\
\hline 7 & $\begin{array}{l}\text { \$diabetes } \quad=\quad \text { filter_var }(\$ o b j- \\
>\text { diabetes, }\end{array}$ \\
\hline 8 & $\begin{array}{l}\text { FILTER_SANITIZE_NUMBER_INT); } \\
\text { \$kolesterol = filter_var(\$obj- } \\
\text { >kolesterol, }\end{array}$ \\
\hline 9 & $\begin{array}{l}\text { FILTER_SANITIZE_NUMBER_INT); } \\
\text { \$aktivitas_fisik = filter_var(\$obj- } \\
\text { >aktivitas_fisik, } \\
\text { FILTER_SANITIZE_STRING, }\end{array}$ \\
\hline 10 & FILTER_FLAG_ENCŌDE_LOW) ; \\
\hline $\begin{array}{l}11 \\
12\end{array}$ & 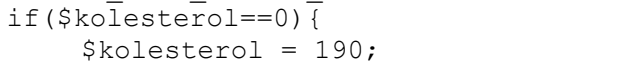 \\
\hline 13 & s \\
\hline 14 & if $(\$ d i a b e s t e s==0)\{$ \\
\hline 15 & $\$$ diabetes $=200$ \\
\hline $\begin{array}{l}17 \\
18\end{array}$ & $\begin{array}{l}\text { \$imt } \\
\text { \$berat_badan/((\$tinggi_badan/100)*(\$ } \\
\text { tinggi_badan/100)); } \\
\text { try }\{\end{array}$ \\
\hline & $\begin{array}{l}\text { stmt }=\text { \$pdo->query('SELECT } \\
\text { id_data,tinggi_badan, berat_badan, fib } \\
\text { rilasi,riwayat_keluarga, tekanan_dara } \\
\text { h, merokok, diabetes, kolesterol, aktivi }\end{array}$ \\
\hline & tas_fisik,imt,kelas FROM \\
\hline 19 & $\begin{array}{ccc}\text { data_training ORDER BY id_data ASC') ; } & \begin{array}{c}\text { ( } \\
\text { while (\$row }\end{array} & \text { \$stmt- }\end{array}$ \\
\hline $\begin{array}{l}20 \\
21\end{array}$ & $\begin{aligned}>\text { fetch }(\text { PDO : : } & \text { EETCH_OBJ })) \\
& \text { \$data }[]=\text { \$row }\end{aligned}$ \\
\hline 22 & $\begin{array}{l}\text { \$rekomen } \\
\text { rekomendasi (\$data, \$tinggi_badan, \$ber } \\
\text { at_badan, \$fibrilasi, \$riwayat_keluarg } \\
\text { a, \$tekanan_darah, \$merokok, \$diabetes, }\end{array}$ \\
\hline 23 & $\begin{array}{l}\text { \$kolesterō̄,\$aktivitas_fisik); } \\
\text { \$tinggi_badan }\end{array}$ \\
\hline 24 & $\begin{array}{l}\text { normalisasi_tinggi(\$tinggi_badan); } \\
\text { \$berat_badan }\end{array}$ \\
\hline 25 & $\begin{array}{l}\text { normalísasi_berat(\$berat_badan); } \\
\text { \$diabetes }\end{array}$ \\
\hline 26 & $\begin{array}{l}\text { normalisasi_diabetes (\$diabetes); } \\
\text { \$kolesterol }\end{array}$ \\
\hline 27 & normalisasi_kolesterol (\$kolesterol); \\
\hline 28 & $\begin{array}{l}\text { \$vote } \\
\text { hitungKNN (\$data, \$tinggi_badan, \$berat } \\
\text { badan, \$fibrilasi, \$riwayat_keluarga, } \\
\text { \$tekanan_darah, \$merokok, \$diabetes, } \$ \text { k }\end{array}$ \\
\hline $\begin{array}{l}29 \\
30\end{array}$ & $\begin{array}{l}\text { olesterol, \$aktivitas_fisik, \$imt); } \\
\text { \$maksimal }=\max (\text { \$vote) })\end{array}$ \\
\hline 31 & \$klasifikasi = "asd"; \\
\hline 32 & if $(\$$ maksimal $==$ \$vote $[0])\{$ \\
\hline 33 & \$klasifikasi = "tinggi"; \\
\hline
\end{tabular}

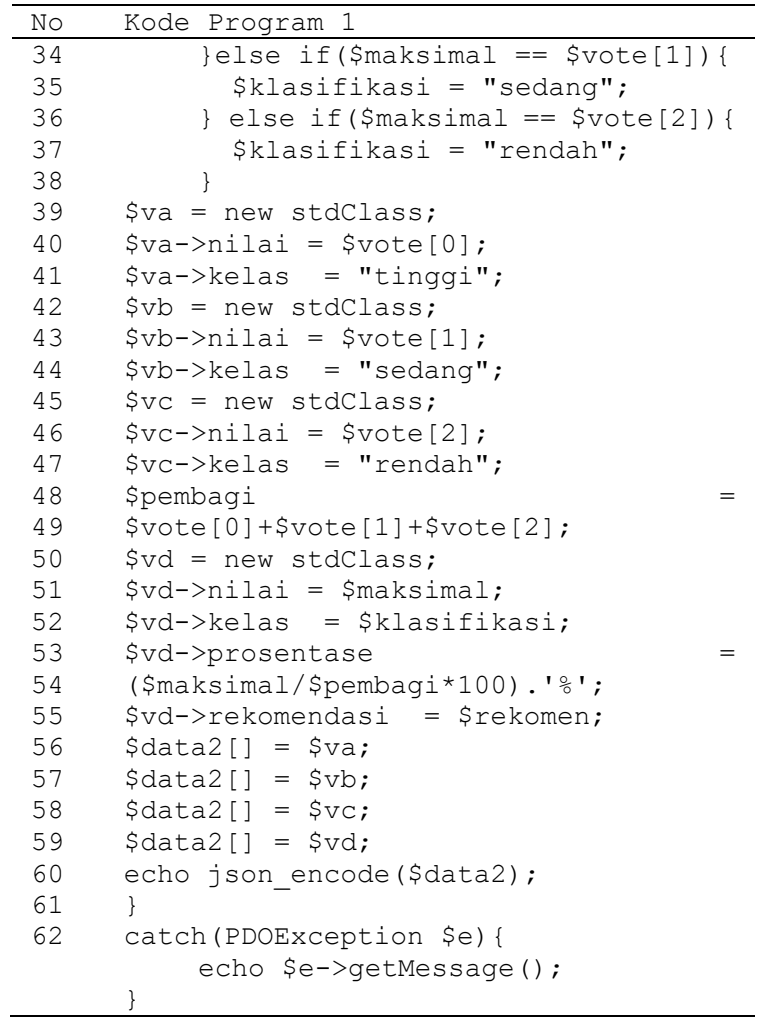

Pembahasan Kode Program 1

1. Baris 1-9 merupakan baris untuk mengambil nilai input dari pengguna

2. Baris 10-15 merupakan baris untuk mengubah nilai kolesterol dan diabetes ke nilai median apabila pengguna tidak mengetahuinya

3. Baris 17-28 merupakan baris untuk mengambil data latih dari database, lalu melakukan perihitungan dan memberikan rekomendasi

4. Baris 29-37 merupakan baris untuk melakukan vote untuk menentukan kelas data

5. Baris 38-59 merupakan baris untuk memasukkan data pada variabel php dan menjadikannya ke dalam format JSON untuk ditampilkan pada aplikasi

6. Baris 60-62 merupakan baris untuk mengembalikan nilai error 


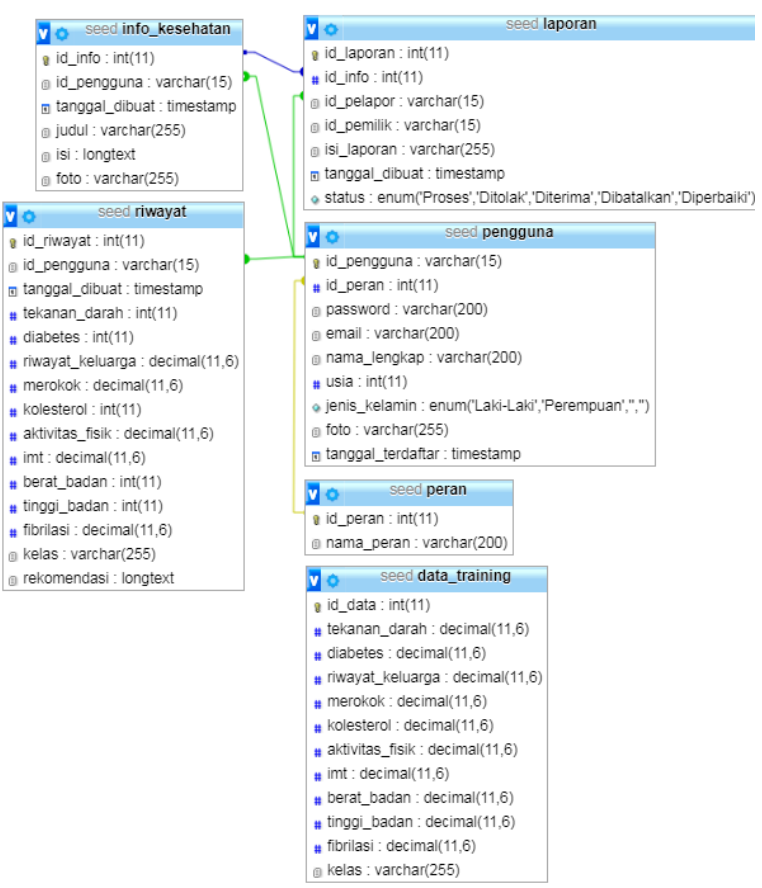

Gambar 6. Tabel pada database

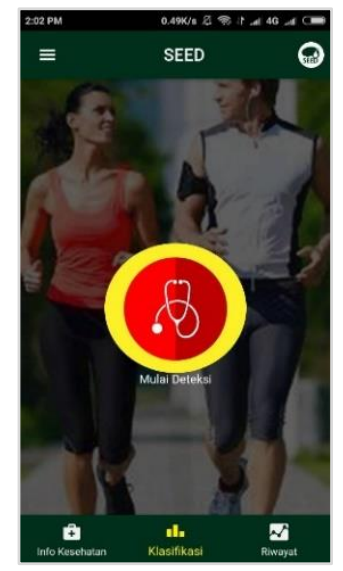

Gambar 7. Halaman Awal

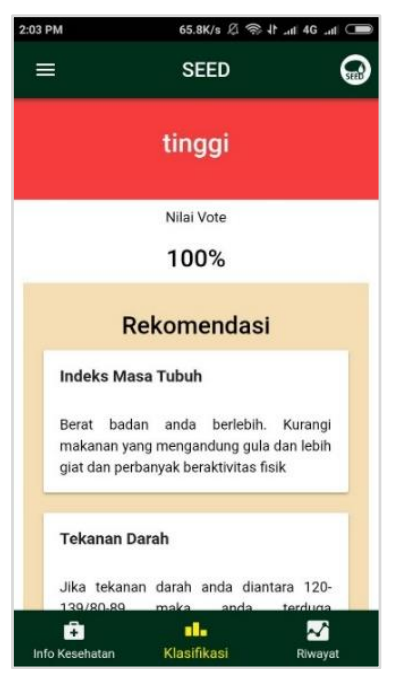

Gambar 8. Hasil dan Rekomendasi

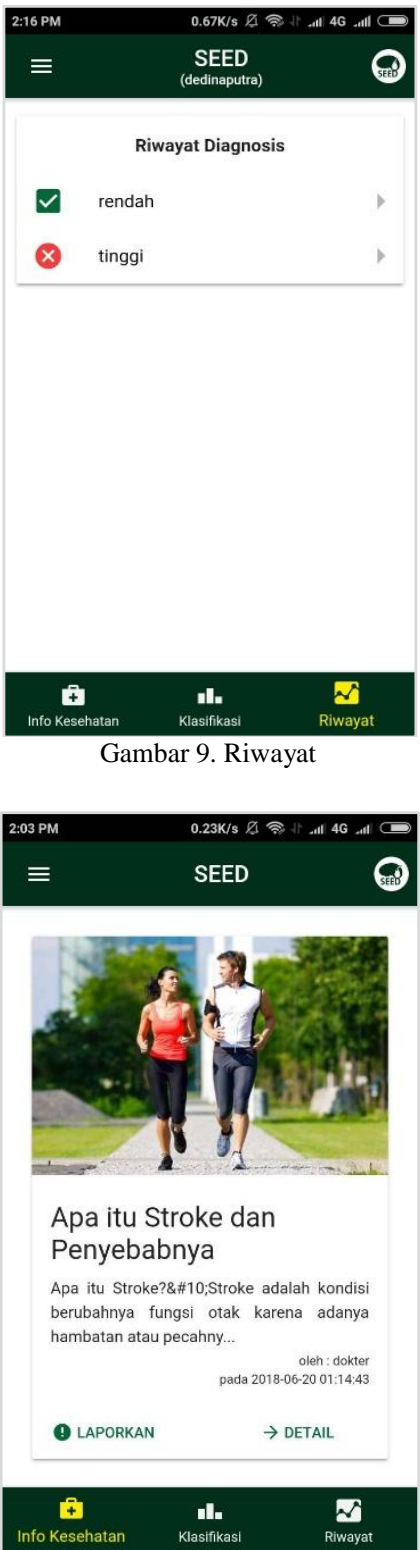

Gambar 10. Informasi Kesehatan

\section{PENGUJIAN}

\subsection{Pengujian validasi}

Pengujian validasi dilakukan dengan menggunakan metode blackbox. Pengujian ini dilakukan dengan mencocokkan hasil implementasi dengan kebutuhan awal yang telah didefinisikan.

\begin{tabular}{lll}
\multicolumn{3}{c}{ Tabel 1. Pengujian Validasi } \\
\hline No & \multicolumn{1}{c}{ Nama Kasus Uji } & \multicolumn{1}{c}{ Status } \\
& & Validitas \\
\hline 1 & Mendaftar & Valid \\
2 & Masuk & Valid \\
3 & Keluar & Valid \\
4 & Melihat Info Kesehatan & Valid \\
5 & Melakukan Pengaduan & Valid \\
6 & Input Gejala & Valid \\
7 & Prediksi Gejala & Valid \\
8 & Rekomendasi Tindakan & Valid \\
\hline
\end{tabular}




\begin{tabular}{lll}
\hline No & \multicolumn{1}{c}{ Nama Kasus Uji } & \multicolumn{1}{c}{$\begin{array}{c}\text { Status } \\
\text { Validitas }\end{array}$} \\
\hline 9 & Menyimpan Riwayat & Valid \\
10 & Menghappus Riwayat & Valid \\
11 & Melihat Riwayat & Valid \\
12 & Menambah Info Kesehatam & Valid \\
13 & Mengubah Info Kesehatan & Valid \\
14 & Menghapus Info Kesehatan & Valid \\
15 & Melihat Peringatan & Valid \\
16 & Menambah Pengguna & Valid \\
17 & Menghapus Pengguna & Valid \\
18 & Memberikan Peringatan & Valid \\
19 & Availibility & Valid \\
20 & Performance & Valid \\
21 & Security & Valid \\
\hline
\end{tabular}

\subsection{Pengujian akurasi}

Pengujian akurasi dilakukan dengan menggunakan confussion matrix,

Tabel 2. Pengujian Akurasi

\begin{tabular}{|c|c|c|c|c|}
\hline & \multicolumn{4}{|c|}{ Predicted } \\
\hline \multirow{4}{*}{$\begin{array}{l}\text { Actual } \\
\text { Result }\end{array}$} & & Tinggi & Sedang & Rendah \\
\hline & Tinggi & $9(\mathrm{TPt})$ & 0 (Ets) & 1 (Etr) \\
\hline & & 2 (Est) & 6 (TPs) & 0 (Esr) \\
\hline & Rendah & 0 (Ert) & 0 (Ers) & 7 (TPr) \\
\hline
\end{tabular}

$\begin{array}{lll}\text { Presisi kelas } & = & \mathrm{TPt} /(\mathrm{TPt}+\text { Est }+ \text { Ert })=9 /(9+2)= \\ \text { Tinggi } & & 9 / 11=0,812 \\ \text { Precission kelas } & & \mathrm{TPs} /(\mathrm{TPs}+\text { Ets }+ \text { Ers })=6 /(6+0)= \\ \text { Sedang } & 6 / 6=1 \\ \text { Precission Kelas } & = & \mathrm{TPr} /(\mathrm{TPr}+\mathrm{Etr}+\mathrm{Esr})=7 /(7+1)= \\ \text { Rendah } & & 0.875 \\ \text { Akurasi } & = & \mathrm{TPa} / \mathrm{TPa}+\mathrm{Ea}=22 / 25=0.88 \\ \text { Keseluruhan } & & \end{array}$

\subsection{Pengujian Penerimaan}

Pengujian penerimaan dilakukan untuk mengetahui sejauh mana pengguna dapat dengan mudah menggunakan aplikasi ini. Adapun parameter pengujian penerimaan dapat dilihat pada Tabel 3 .

\begin{tabular}{|c|c|c|}
\hline No. & Parameter & Pernyataan \\
\hline 1 & Kemudahan & $\begin{array}{l}\text { Saya merasa mudah untuk } \\
\text { menggunakan aplikasi ini }\end{array}$ \\
\hline 2 & Familarity & $\begin{array}{l}\text { Saya merasa familiar dengan } \\
\text { tampilan aplikasi ini }\end{array}$ \\
\hline 3 & $\begin{array}{l}\text { Pemahaman } \\
\text { fitur }\end{array}$ & $\begin{array}{l}\text { Saya mudah memahami fungsi } \\
\text { dan fitur yang disediakan oleh } \\
\text { aplikasi ini }\end{array}$ \\
\hline 4 & Keamanan & $\begin{array}{l}\text { Saya percaya dengan tingkat } \\
\text { keamanan aplikasi ini }\end{array}$ \\
\hline 5 & Helpfull & $\begin{array}{l}\text { Aplikasi ini dapat membantu saya } \\
\text { dalam kegiatan sehari-hari }\end{array}$ \\
\hline 6 & Kecepatan & $\begin{array}{l}\text { Aplikasi ini memiliki tingkat } \\
\text { respon yang cukup cepat }\end{array}$ \\
\hline 7 & Kenyamanan & $\begin{array}{l}\text { Saya merasa nyaman dalam } \\
\text { mengoperasikan aplikasi ini }\end{array}$ \\
\hline
\end{tabular}

Pernyataan pada Tabel 3 akan dijadikan dasar pada penyusunan kuisioner. Jawaban pada kuisioner diukur dengan menggunakan skala likert satu sampai lima. Responden diminta untuk mengoperasilkan aplikasi dan mengisi kuisioner. Dari 8 responden, hasil dari kuisioner secara keseluruhan adalah positif dengan nilai $219 / 280$ atau $78 \%$ dapat diterima.

\section{KESIMPULAN}

Berdasarkan hasil perancangan, implementasi dan pengujian maka dapat disimpulkan bahwa :

1. SEED berhasil diimplementasikan dengan menggunakan aplikasi mobile hybrid dengan validasi kebutuhan bernilai $100 \%$ dan akurasi yang mencapai $88 \%$

2. Terdapat beberapa fitur yang lebih berpengaruh terhadap tingkat akurasi proses klasifikasi. Pengaruh tersebut dapat diwujudkan dalam bentuk bobot diantaranya pada fitur riwayat keluarga (4 kali) dan riwayat fibrilasi atrium (2 kali)

3. SEED dapat diterima oleh pengguna dengan tingkat positif dan nilai penerimaan sebesar $78 \%$ Berdasarkan hasil penilitian, maka untuk proses pengembngan lebih lanjut dapat gal-hal dilakukan sebagai berikut :

1. Meningkatkan akurasi dengan menerapkan algirtme kecerdasan buatan lain dan dapat melakukan proses pre-processing atau pembobotan

2. Menambah fitur aplikasi tidak hanya untuk penyakit stroke melainkan penyakit lain jga.

3. Aplikasi SEED dapat lebih diotomatisasi lagi untuk meningkatkan kemudahan pengguna dengan mengimplementasikan sensor, seperti sensor suara untuk mendeteksi fibrilasi atrium.

\section{DAFTAR PUSTAKA}

ARISETIJONO, 2016. 30 Persen Penderita Stroke Usia Muda. Wawancara pada jpnn.com. https://www.jpnn.com/news/30-persenpenderita-stroke-usia-muda. Diakses pada 13 Oktober 2017, Puluk : 10.20.

\section{BADAN PENELITIAN DAN PENGEMBANGAN KESEHATAN RI, 2013. Laporan Riset Kesehatan Dasar (RISKESDAS) 2013. Jakarta : Kementerian Kesehatan Republik Indonesia.}

\section{KURNIANINGTYAS, DIVA, BRILLIAN} ARISTYO R., DYAN PUTRI M., AMALIA KARTIKA A., DWI ANGRAENI K. 2017. Sistem Pendukung Keputusan Diagnosis Penyakit Sapi Potong Menggunakan kNearest Neighbour (K-NN). Jurnal 
Teknologi Informasi dan Ilmu Komputer,Vol. 4, No.2, hlm. 122-126.

SUCI, WAHYU, ARIEF, A. S., TANZIL, M. F., 2017. Sistem Pakar Deteksi Dini Penyakit Stroke Menggunakan Metode Imporved kNearest Neighbor (KNN)+. [online]. Tersedia melalui <http://filkom.ub.ac.id/doro/archives/detail/ DR00065201706\#> [Diakses 20 Oktober 2017].

SUDHARANI, K, SARMA, SATYA PRASAD.

2015. Brain Stroke Detection Using kNearest Neighbour and Minimum mean Distance Technique. International Conference on Control, Instrumentatiom, Communication and Computation Technologies (ICCICCT), IEEE. hlm. 770776.

STATCOUNTER, 2018. Mobile \& Tabley Operating System Market Share Asia. [online]. Tersedia melalui <http://gs.statcounter.com/os-marketshare/mobile-tablet/worldwide/\#monthly201703-201703-map>. [Diakses 4 Mei 2018]

SYAFIQ, MUHAMMAD, ACHMAD JAFAR A. K., RIZKA HUSNUN Z., DAESWARA JAUHARI, WANDA ATHIRA L., IMAM CHOLISSODIN, LAILIL MULFLIKHAH. 2016. Aplikasi Mobile (LIDE) untuk Diagnosis Tingkat Risiko Penyakit Stroke Menggunakan PTVPSO-SVM. Jurnal Teknologi Informasi dan Ilmu Komputer,Vol. 3, No.2, hlm. 147-155.

WWW.ALODOKTER, 2017. Penyebab Stroke. [online]. Tersedia melalui <http://www.alodokter.com/stroke/penyeba b> [Diakses pada 20 Oktober 2017] 
Halaman ini sengaja dikosongkan 